Annals of Warsaw University of Life Sciences - SGGW

Land Reclamation No 44 (1), 2012: 15-24

(Ann. Warsaw Univ. of Life Sci. - SGGW, Land Reclam. 44 (1), 2012)

\title{
Optimization of water management system operation while quality and quantity of water determined
}

\author{
JOANNA POŁOMSKA, WOJCIECH Z. CHMIELOWSKI \\ Institute of Water Engineering and Management, Cracow University of Technology
}

Key words: water management, water management systems, optimal control.

\section{INTRODUCTION}

Current economic development of urban and industrial agglomerations requires considerable water supplies and the water delivery has to be reliable. Nowadays without planning about water distribution and water storage, it is impossible that water resources are used in the best economic way. While water transportation by pipelines or channels on the area around the water source is considered, some calculations and simulations are needed, so that the real actions could be optimal because of causing minimum costs and maximum benefits. The term 'optimal' may have several different meanings, depends on what is more or less important for us or for surrounding nature represented by its fauna and flora generally.

A typical water management system consisted of water sources (in the article represented by rivers and water reservoirs) and water consumers (in this article there are water purification plants, WPPs, that prepare water for people and industry in agglomerations). The main assumption in the article about the water management system functioning is that, the aim of the water reservoirs is gathering of water for people and industry needs, so floods, droughts, water power engineering, water recreation etc. are not taken into account. The flow rates in the rivers that feed with water the water reservoirs are changeable and, besides, the specified flow rates in the rivers that escape the water reservoirs are required (sustain of biological life in rivers, water demands of other agglomerations etc.), so the purpose of the activity of the water reservoirs is to adjust of the water flow rates and to satisfy the water demands of the agglomerations. When some water shortages occur, water should be gathered in the water reservoirs, as a reserve for a possible period of more serious water restrictions in nature. While optimization, the water manager makes decisions about the controlled water flows and strives for gathering of water in the water reservoirs. When the water reservoirs are not filled up water enough after optimization, then specified costs ( $A_{1}$ cost relation matrix) are generated. The purpose of the water management system is also to supply water to the agglomerations. When the amounts of water delivered to the agglomerations are not sufficient then specific economic costs are generated ( $\mathbf{A}_{\mathbf{2}}$ cost relation ma- 
trix). The costs of water purification $\left(\mathbf{A}_{\mathbf{3}}\right.$ and $\mathbf{A}_{\mathbf{4}}$ cost relation matrixes) depend on the quality of water, defined by the kinds of pollutants and the concentrations of various contaminating substances. In this work the quality of water is represented by two indexes: 5-day biochemical oxygen demand $B O D_{5}$ and chemi- cal oxygen demand $C O D$. Besides, it is possible that the water in the water reservoirs may be contaminated very seriously (the concentrations of pollution over maximum acceptable values) so the usage of the water by people is impossible then. The next kind of the costs of the water management system function-

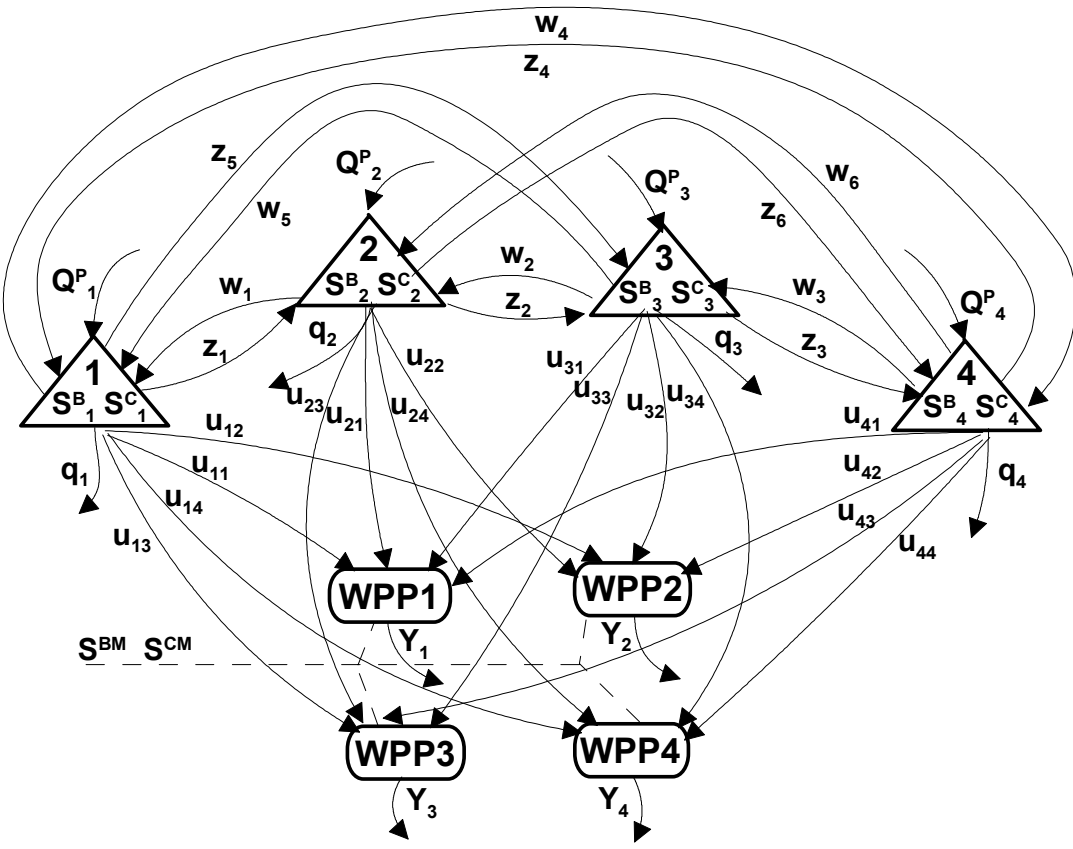

FIGURE 1. The scheme of the considered water management system, where:

$\Delta \quad$ - symbol represented a water reservoir,

WPP - symbol represented a water purification plant,

$\boldsymbol{Q}^{\boldsymbol{P}}(t)_{4 \times 1}$ - vector of the expected inflows to the water reservoirs $\left[\mathrm{m}^{3} / \mathrm{s}\right]$,

$\boldsymbol{q}(t) 4 \times 1-$ vector of the required outflows from the water reservoirs $\left[\mathrm{m}^{3} / \mathrm{s}\right]$,

$\mathbf{S}^{\mathbf{B}}(t) 4 \times 4 \quad$ - matrix of expected $B O D_{5}$ (5-day biochemical oxygen demand) concentration in water in the water reservoirs $\left[\mathrm{g} / \mathrm{m}^{3}\right]$,

$\mathbf{S}^{\mathbf{C}}(t) 4 \times 4$ - matrix of expected COD (chemical oxygen demand) concentration in water in the water reservoirs $\left[\mathrm{g} / \mathrm{m}^{3}\right]$,

$\mathbf{S}^{\mathbf{B M}_{4 \times 4}}$ - matrix of maximum $B O D_{5}$ concentration; when the value is exceeded, the water mustn't be used as drinking water for people and animals $\left[\mathrm{g} / \mathrm{m}^{3}\right]$,

$\mathbf{S}^{\mathbf{C M}_{4 \times 4}}$ - matrix of maximum $C O D$ concentration; when the value is exceeded, the water mustn't be used as drinking water for people and animals $\left[\mathrm{g} / \mathrm{m}^{3}\right]$,

$\boldsymbol{Y}(t)_{4 \times 1}-$ vector of water demands for the WPPs (required inflows) $\left[\mathrm{m}^{3} / \mathrm{s}\right]$,

$\boldsymbol{u}(t) 4 \times 1 \quad-$ vector of water flows from the water reservoirs to the WPPs $\left[\mathrm{m}^{3} / \mathrm{s}\right]$,

$\boldsymbol{w}(t)_{6 \times 1}-$ vector of water flows among the water reservoirs $\left[\mathrm{m}^{3} / \mathrm{s}\right]$,

$\boldsymbol{z}(t) 6 \times 1-$ vector of water flows among the water reservoirs $\left[\mathrm{m}^{3} / \mathrm{s}\right]$. 
ing are concerned to the transportation of water, so if the proper infrastructure is existed, it includes e.g. driving of the pumping plants $\left(\mathbf{A}_{5}, \mathbf{A}_{\mathbf{6}} / \mathbf{A}_{7}\right.$ cost relation matrixes). All the above mentioned costs of the operation of the water management system influence the value of the quality factor $F$ formulated below. The scheme of the water management system is in the Figure 1.

\section{SOLUTION}

To make optimal model for computing and simulations, the quality factor $F$ was formulated by using the Pontryagin's maximum principle, and optimal flows, so $\boldsymbol{u}(t), \boldsymbol{z}(t)$ and $\boldsymbol{w}(t)$, may be estimated. The aim of the model is to minimize the cost of the water management system functioning.

$F=0.5\left[x^{W}(T)-x_{k}(T)\right]_{(+)}^{\mathbf{T}} \cdot \mathbf{A}_{\mathbf{1}} \cdot$

$\cdot\left[x^{W}(T)-x_{k}(T)\right]_{(+)}+0.5 \cdot$

- $\left\{\right.$ to $^{T} \int^{T}\left\{[\mathbf{S} \cdot \mathbf{B}(t) \cdot \boldsymbol{Y}(t)-\boldsymbol{u}(t)]^{\mathbf{T}}{ }_{(+)} \cdot \mathbf{A}_{2}[\mathbf{S} \cdot\right.$

$\cdot \mathbf{B}(t) \cdot \boldsymbol{Y}(t)-\boldsymbol{u}(t)]_{(+)}+\left[\mathbf{S} \cdot \mathbf{S}^{\mathbf{B}}(t) \cdot\right.$

$\cdot[\boldsymbol{u}(t)-\mathbf{D}(t) \cdot \boldsymbol{Y}(t)]]_{(+)}^{\mathbf{T}} \cdot \mathbf{A}_{\mathbf{3}}\left[\mathbf{S} \cdot \mathbf{S}^{\mathbf{B}}(t) \cdot\right.$

$\cdot[\boldsymbol{u}(t)-\mathbf{D}(t) \cdot \boldsymbol{Y}(t)]]_{(+)}+\left[\mathbf{S} \cdot \mathbf{S}^{\mathbf{C}}(t) \cdot\right.$

$\cdot[\boldsymbol{u}(t)-\mathbf{E}(t) \cdot \boldsymbol{Y}(t)]]_{(+)}^{\mathbf{T}} \cdot \mathbf{A}_{4}\left[\mathbf{S} \cdot \mathbf{S C}_{(t)} \cdot\right.$

- $[\boldsymbol{u}(t)-\mathbf{E}(t) \cdot \boldsymbol{Y}(t)]]_{(+)}+\boldsymbol{u}^{\mathbf{T}}(t) \cdot \mathbf{A}_{\mathbf{5}} \cdot$

$\cdot \boldsymbol{u}(t)+\boldsymbol{z}^{\mathbf{T}}(t) \cdot \mathbf{A}_{\mathbf{6}} \cdot \boldsymbol{z}(t)+\boldsymbol{w}^{\mathbf{T}}(t) \cdot \mathbf{A}_{\mathbf{7}} \cdot$

$\cdot \boldsymbol{w}(t)\} d t\}$

where:

$F$ - quality factor,

$\mathbf{A}_{1^{4 \times 4}}$ - matrix of validity ratios related to the costs resulted from not gathering enough water in the water reservoirs $\left[\mathrm{PLN} / \mathrm{m}^{3}\right]$,

$\mathbf{A}_{2^{4 \times 4}}$ - matrix of validity ratios related to the costs resulted from not supplying enough water to the WPPs [PLN $\left./ \mathrm{m}^{3}\right]$,

$\mathbf{A}_{3^{4 \times 4}}-$ matrix of validity ratios related to the costs resulted from the water pu- rification processes because of $B O D_{5}$ $[\mathrm{PLN} / \mathrm{g}$ ],

$\mathbf{A}_{4^{4 \times 4}}$ - matrix of validity ratios related to the costs resulted from the water purification processes because of $C O D[\mathrm{PLN} / \mathrm{g}]$, $\mathbf{A}_{5^{4 \times 4}}$ - matrix of validity ratios related to the costs resulted from the water transportation form the water reservoirs to the WPPs [PLN $\left./ \mathrm{m}^{3}\right]$,

$\mathbf{A}_{6^{6 \times 6}}$ - matrix of validity ratios related to the costs resulted from the water transportation among the water reservoirs $\left[\mathrm{PLN} / \mathrm{m}^{3}\right]$,

$\mathbf{A}_{7^{6 \times 6}}-$ matrix of validity ratios related to the costs resulted from the water transportation among the water reservoirs $\left[\mathrm{PLN} / \mathrm{m}^{3}\right]$,

$\mathbf{B}(t)_{4 \times 4}$ - matrix of validity ratios related to the involvements of the water reservoirs for the satisfaction of the demands of the WPPs [-],

$\mathbf{D}(t)_{4 \times 4}-$ matrix of validity ratios related to the involvements of the water reservoirs for the satisfaction of the demands of the WPPs concerning $B O D_{5}$ concentration in water [-],

$\mathbf{E}(t)_{4 \times 4}$ - matrix of validity ratios related to the involvements of the water reservoirs for the satisfaction of the demands of the WPPs concerning COD concentration in water [-],

$\mathbf{S}_{4 \times 4}-$ matrix of the structural connections of the water reservoirs and the WPPs [-],

$\boldsymbol{x}_{\boldsymbol{k}}(T)_{4 \times 1}-$ vector of quantities of water gathered actually in the water reservoirs at the end of the optimization $\left[\mathrm{m}^{3}\right]$,

$\boldsymbol{x}^{W}(T)_{4 \times 4}$ - vector of quantities of water required to be gathered in the water reservoirs at the end of the optimization $\left[\mathrm{m}^{3}\right]$,

$t_{o}$ - the beginning time of the optimization $[\mathrm{s}]$, 
$T$ - the duration of the optimization [s].

The equation of state is the following:

$\dot{x}(t)=\boldsymbol{Q}^{\boldsymbol{P}}(t)-\mathbf{S}_{\mathbf{1}} \cdot \boldsymbol{u}(t)+\mathbf{S}_{\mathbf{2}} \cdot(\boldsymbol{z}(t)-$

$-\boldsymbol{w}(t))-\boldsymbol{q}(t)$

where:

$\dot{x}(t)_{4 \times 1}-$ vector of the state derivatives $\left[\mathrm{m}^{3} / \mathrm{s}\right]$,

$\mathbf{S}_{14 \times 4}$ - matrix of the possible water distribution form the water reservoirs to the WPPs [-],

$\mathbf{S}_{\mathbf{2 4 \times 6}}$ - matrix of the possible water distribution among the water reservoirs [-].

When the quality factor (1) and the equation of state (2) are considered, the Hamiltonian function is as follows (3):

$H=-0.5\left\{[\mathbf{S} \cdot \mathbf{B}(t) \cdot \boldsymbol{Y}(t)-\boldsymbol{u}(t)]_{(+)}^{\mathbf{T}}{ }^{\circ}\right.$

$\cdot \mathbf{A}_{2}[\mathbf{S} \cdot \mathbf{B}(t) \cdot \boldsymbol{Y}(t)-\boldsymbol{u}(t)]_{(+)}+\left[\mathbf{S} \cdot \mathbf{S}^{\mathbf{B}}(t) \cdot\right.$

$\cdot[\boldsymbol{u}(t)-\mathbf{D}(t) \cdot \boldsymbol{Y}(t)]]_{(+)}^{\mathbf{T}} \cdot \mathbf{A}_{\mathbf{3}}\left[\mathbf{S} \cdot \mathbf{S}^{\mathbf{B}}(t) \cdot\right.$

$\cdot[\boldsymbol{u}(t)-\mathbf{D}(t) \cdot \boldsymbol{Y}(t)]]_{(+)}+\left[\mathbf{S} \cdot \mathbf{S}^{\mathbf{C}}(t) \cdot\right.$

$\cdot[\boldsymbol{u}(t)-\mathbf{E}(t) \cdot \boldsymbol{Y}(t)]]_{(+)}^{\mathbf{T}} \cdot \mathbf{A}_{4}\left[\mathbf{S} \cdot \mathbf{S}_{(t)} \cdot\right.$

$\cdot[\boldsymbol{u}(t)-\mathbf{E}(t) \cdot \boldsymbol{Y}(t)]]_{(+)}+\boldsymbol{u}^{\mathbf{T}}(t) \cdot \mathbf{A}_{\mathbf{5}} \cdot$

$\cdot \boldsymbol{u}(t)+\boldsymbol{z}^{\mathbf{T}}(t) \cdot \mathbf{A}_{\mathbf{6}} \cdot \boldsymbol{z}(t)+\boldsymbol{w}^{\mathbf{T}}(\mathbf{t}) \cdot \mathbf{A}_{7} \cdot$

$\cdot \boldsymbol{w}(t)\}+\boldsymbol{\eta}^{\mathbf{T}}(t) \cdot\left(\boldsymbol{Q}^{\boldsymbol{P}}(t)-\mathbf{S}_{\mathbf{1}} \cdot \boldsymbol{u}(t)+\mathbf{S}_{\mathbf{2}} \cdot\right.$

$\cdot(z(t)-\boldsymbol{w}(t))-\boldsymbol{q}(t))$

where:

$H$ - Hamiltonian function,

$\boldsymbol{\eta}(t)_{4 \times 4}-$ vector of the variables conjugated with the state equation [-].

The presented dynamic optimization problem was solved according to Pontryagin's maximum principle:

1. $\left(\nabla_{\boldsymbol{u}(t)} H\right)^{\mathbf{T}}=\mathbf{0}$

$\hat{\boldsymbol{u}}(t)=\left\{-\mathbf{A}_{\mathbf{2}}-\mathbf{A}_{\mathbf{5}}-\mathbf{S}^{\mathbf{B}}(t) \cdot \mathbf{S} \cdot \mathbf{A}_{\mathbf{3}} \cdot \mathbf{S} \cdot\right.$

$\left.\cdot \mathbf{S}^{\mathbf{B}}(t)-\mathbf{S}^{\mathbf{C}}(t) \cdot \mathbf{S} \cdot \mathbf{A}_{\mathbf{4}} \cdot \mathbf{S} \cdot \mathbf{S}^{\mathbf{C}}(t)\right\}^{-1}$.

$\cdot\left\{\left[-\mathbf{A}_{\mathbf{2}} \cdot \mathbf{S} \cdot \mathbf{B}(t)-\mathbf{S}^{\mathbf{B}}(t) \cdot \mathbf{S} \cdot \mathbf{A}_{\mathbf{3}} \cdot \mathbf{S} \cdot\right.\right.$

- $\mathbf{D}(t) \cdot \mathbf{S}^{\mathbf{B}}(t)-\mathbf{S}^{\mathbf{C}}(t) \cdot \mathbf{S} \cdot \mathbf{A}_{\mathbf{4}} \cdot \mathbf{S} \cdot \mathbf{E}(t) \cdot$

$\left.\left.\cdot \mathbf{S}^{\mathbf{C}}(t)\right] \cdot \boldsymbol{Y}(t)+\mathbf{S}_{\mathbf{1}} \mathbf{T}^{\mathbf{T}} \cdot \hat{\boldsymbol{\eta}}(\mathrm{t})\right\}$
Some additional variables were formulated and the above equation was written as follows:

$$
\hat{\boldsymbol{u}}(t)=\mathbf{K}_{\mathbf{1}}(t) \cdot\left[\mathbf{K}_{\mathbf{2}}(t)+\mathbf{S}_{\mathbf{1}}{ }^{\mathbf{T}} \cdot \hat{\boldsymbol{\eta}}(t)\right]
$$

where:

$\mathbf{K}_{\mathbf{1}}(t)=\left\{-\mathbf{A}_{\mathbf{2}}-\mathbf{A}_{\mathbf{5}}-\mathbf{S}^{\mathbf{B}}(t) \cdot \mathbf{S} \cdot \mathbf{A}_{\mathbf{3}} \cdot \mathbf{S} \cdot\right.$

$\left.\cdot \mathbf{S}^{\mathbf{B}}(t)-\mathbf{S}^{\mathbf{C}}(t) \cdot \mathbf{S} \cdot \mathbf{A}_{\mathbf{4}} \cdot \mathbf{S} \cdot \mathbf{S}^{\mathbf{C}}(t)\right\}^{-1}$

$\mathbf{K}_{\mathbf{2}}(t)=\left[-\mathbf{A}_{\mathbf{2}} \cdot \mathbf{S} \cdot \mathbf{B}(t)-\mathbf{S}^{\mathbf{B}}(t) \cdot \mathbf{S} \cdot \mathbf{A}_{\mathbf{3}} \cdot\right.$

$\mathbf{S} \cdot \mathbf{D}(t) \cdot \mathbf{S}^{\mathbf{B}}(t)-\mathbf{S}^{\mathbf{C}}(t) \cdot \mathbf{S} \cdot \mathbf{A}_{\mathbf{4}} \cdot \mathbf{S} \cdot \mathbf{E}(t) \cdot$

- $\left.\mathbf{S}^{\mathbf{C}}(t)\right] \cdot \boldsymbol{Y}(t)$

2. $\left(\nabla_{z(t)} H\right)^{\mathbf{T}}=\mathbf{0}$

$\hat{\boldsymbol{z}}(t)=-\mathbf{A}_{\mathbf{6}}{ }^{-\mathbf{1}} \cdot \mathbf{S}_{\mathbf{2}}{ }^{\mathbf{T}} \cdot \hat{\boldsymbol{\eta}}(t)$

3. $\left(\nabla_{\boldsymbol{w}(t)} H\right)^{\mathbf{T}}=\mathbf{0}$

$\hat{\boldsymbol{w}}(t)=\mathbf{A}_{\mathbf{7}}{ }^{\mathbf{1}} \cdot \mathbf{S}_{\mathbf{2}}^{\mathbf{T}} \cdot \hat{\boldsymbol{\eta}}(t)$

4. $\left(\nabla_{\boldsymbol{\eta}(t)} H\right)^{\mathbf{T}}=\dot{x}(t)$

$\dot{x}(t)=Q^{P}(t)-\mathbf{S}_{\mathbf{1}} \cdot \hat{\boldsymbol{u}}(t)+\mathbf{S}_{\mathbf{2}} \cdot(\hat{z}(t)-$

$-\hat{\boldsymbol{w}}(t))-\boldsymbol{q}(t)$

5. $\left(-\nabla_{\boldsymbol{x}(t)} H\right)^{\mathbf{T}}=\dot{\eta}(t)$

$\dot{\eta}(t)=\mathbf{0} \quad \Rightarrow \quad \hat{\eta}(t)=C_{\boldsymbol{1}}$

6. $\left(-\nabla_{\boldsymbol{x}(T)} K\right)^{\mathbf{T}}=\hat{\boldsymbol{\eta}}(T)$

$\hat{\boldsymbol{\eta}}(T)=\mathbf{A}_{\mathbf{1}} \cdot\left[\boldsymbol{x}^{\boldsymbol{W}}(T)-\boldsymbol{x}_{\boldsymbol{k}}(T)\right]$

When (14) was integrated and $\boldsymbol{u}(t), \boldsymbol{z}(t)$, $\boldsymbol{w}(t)$ and $\boldsymbol{\eta}(t)$ were replaced (6), (10), (12) and (16), $\boldsymbol{C}_{\boldsymbol{1}}$ vector was calculated:

$\boldsymbol{x}(t)={ }_{t o} \int^{T}\left\{\boldsymbol{Q}^{\boldsymbol{P}}(t)-\mathbf{S}_{\mathbf{1}} \cdot \mathbf{K}_{\mathbf{1}}(t) \cdot\right.$

$\cdot\left[\mathbf{K}_{\mathbf{2}}(t)+\mathbf{S}_{\mathbf{1}} \mathbf{T}^{\mathbf{T}} \hat{\boldsymbol{\eta}}(T)\right]-\mathbf{S}_{\mathbf{2}} \cdot\left(\mathbf{A}_{\mathbf{6}}{ }^{-\mathbf{1}}+\right.$ $\left.\left.+\mathbf{A}_{\mathbf{7}}{ }^{-1}\right) \cdot \mathbf{S}_{\mathbf{2}}{ }^{\mathbf{T}} \cdot \hat{\boldsymbol{\eta}}(T)-\boldsymbol{q}(t)\right\} d t+\boldsymbol{x}\left(t_{o}\right)$,

and

$\boldsymbol{C}_{\boldsymbol{1}}=\mathbf{A}_{\mathbf{1}} \cdot\left\{\boldsymbol{x}^{\boldsymbol{W}}(T)-\boldsymbol{x}\left(t_{o}\right)-{ }_{t o} \int^{T}\left(\boldsymbol{Q}^{\boldsymbol{P}}(t)\right.\right.$

$\left.-\mathbf{S}_{\mathbf{1}} \cdot \mathbf{K}_{\mathbf{1}}(t) \cdot \mathbf{K}_{\mathbf{2}}(t)-\boldsymbol{q}(t)\right) d t+$

$+\left[{ }_{t o}{ }^{T} \mathbf{S}_{\mathbf{1}} \cdot \mathbf{K}_{\mathbf{1}}(t) \cdot \mathbf{S}_{\mathbf{1}}{ }^{\mathbf{T}} d t+\mathbf{S}_{\mathbf{2}} \cdot\left(\mathbf{A}_{\mathbf{6}}{ }^{-\mathbf{1}}+\right.\right.$

$\left.\left.\left.\mathbf{A}_{7}^{-1}\right) \cdot \mathbf{S}_{\mathbf{2}}{ }^{\mathbf{T}}\right] \cdot \boldsymbol{C}_{\mathbf{1}} \cdot T\right\}$, 
and as the result of some transformations:

$\boldsymbol{C}_{\mathbf{1}}=\left\{\mathbf{I}-\mathbf{A}_{\mathbf{1}} \cdot\left[{ }_{t o}{ }^{T} \mathbf{S}_{\mathbf{1}} \cdot \mathbf{K}_{\mathbf{1}}(t) \cdot \mathbf{S}_{\mathbf{1}} \mathbf{T} d t+\right.\right.$ $\left.\left.+\mathbf{S}_{\mathbf{2}} \cdot\left(\mathbf{A}_{\mathbf{6}}{ }^{-1}+\mathbf{A}_{7}^{-1}\right) \cdot \mathbf{S}_{\mathbf{2}}^{\mathbf{T}}\right] \cdot T\right\}^{-1}$.

$\cdot \mathbf{A}_{\mathbf{1}} \cdot\left[\boldsymbol{x}^{W}(T)-\boldsymbol{x}\left(t_{o}\right)-{ }_{t o}\right]^{T}\left\{\boldsymbol{Q}^{P}(t)-\mathbf{S}_{\mathbf{1}} \cdot\right.$

$\left.\left.\cdot \mathbf{K}_{\mathbf{1}}(t) \cdot \mathbf{K}_{\mathbf{2}}(t)-\boldsymbol{q}(t)\right\} d t\right]$

Next $\boldsymbol{C}_{\boldsymbol{1}}$ was put in (6), (10), (12) and $\hat{\boldsymbol{u}}(t)$, $\hat{z}(t), \hat{\boldsymbol{w}}(t)$ were obtained.

To calculate the value of the quality factor $F(1)$, the values of the elements of $\mathbf{B}(t), \mathbf{D}(t), \mathbf{E}(t)$ matrixes have to be defined.

$\left\{\mathbf{B}_{\mathbf{i}}(t)=\left[{ }_{t o}{ }^{T}\left(\boldsymbol{Q}^{\boldsymbol{P}_{\boldsymbol{i}}}(t)-\boldsymbol{q}_{\boldsymbol{i}}(t)\right) d t+\boldsymbol{x}_{\boldsymbol{i}}\left(t_{o}\right)\right.\right.$

$\left.-\boldsymbol{x}^{\boldsymbol{W}}{ }_{i}(T)\right] / \sum_{i=1}^{4}\left[{ }_{t o}{ }^{T}\left(\boldsymbol{Q}^{\boldsymbol{P}}{ }_{\boldsymbol{i}}(t)-\boldsymbol{q}_{\boldsymbol{i}}(t)\right) d t+\right.$

$\left.+\boldsymbol{x}_{i}\left(t_{o}\right)-\boldsymbol{x}_{i}{ }_{i}(T)\right]$

i $\mathbf{D}_{\mathbf{i}}(t)=T^{-1} \cdot{ }_{t o}{ }^{T} \mathbf{S}^{\mathbf{B}}(t) d t / \mathbf{S}^{\mathbf{B}}(t)_{\mathrm{i}} /$

$/ \sum_{i=1}^{4} T^{-1} \cdot{ }_{t o}{ }^{T} \mathbf{S}^{\mathbf{B}}(t) d t / \mathbf{S}^{\mathbf{B}}(t)_{\mathrm{i}}$

i $\mathbf{E}_{\mathbf{i}}(t)=T^{-1} \cdot{ }_{t o} \int^{T} \mathbf{S}^{\mathbf{C}}(t) d t / \mathbf{S}^{\mathbf{C}}(t)_{\mathrm{i}} /$

$\sum_{i=1}^{4} T^{-1} \cdot{ }_{t o} \int^{T} \mathbf{S}^{\mathbf{C}}(t) d t / \mathbf{S}^{\mathbf{C}}(t)_{\mathrm{i}}$

i $\mathbf{S}_{\mathbf{i}}^{\mathbf{B}}(t) \leq \mathbf{S}^{\mathbf{B M}} \quad$ i $\left.\quad \mathbf{S}^{\mathbf{C}}{ }_{\mathbf{i}}(t) \leq \mathbf{S}^{\mathbf{C M}}\right\}$

$\operatorname{lub}\left[\left(\mathbf{B}_{\mathbf{i}}(t)=\mathbf{0}\right.\right.$ i $\mathbf{D}_{\mathbf{i}}(t)=\mathbf{0}$ i $\left.\mathbf{E}_{\mathbf{i}}(t)=\mathbf{0}\right)$

$\mathrm{i}\left(\mathbf{S}_{\mathbf{i}}^{\mathbf{B}}(t)>\mathbf{S}^{\mathbf{B M}}\right.$ lub $\left.\left.\mathbf{S}_{\mathbf{i}}^{\mathbf{C}}(t)>\mathbf{S}^{\mathbf{C M}}\right)\right](25)$

where:

$\mathrm{i}$ - the subsequent numbers of the water reservoirs, $i=1 \ldots 4$.

\section{RESULTS}

To execute the calculations, the following data were used:

- the system initial conditions: the volumes of water in the water reservoirs $\boldsymbol{x}\left(t_{o}\right)$, the expected inflows $\boldsymbol{Q}^{\boldsymbol{P}}(t)$ and the required outflows $\boldsymbol{q}(t)$ (presented in the graphs below); and the demands for the system functioning - the requirements for the water reservoirs $\boldsymbol{x}^{W}(T)$ and the water demands for the WPPs $\boldsymbol{Y}(t)$ :

$\boldsymbol{x}\left(t_{o}\right)=\left[\begin{array}{c}700 \\ 705 \\ 710 \\ 715\end{array}\right], \boldsymbol{x}^{W}(T)=\left[\begin{array}{l}710 \\ 720 \\ 730 \\ 740\end{array}\right]$,

$\boldsymbol{Y}(t)=\left[\begin{array}{l}3.5 \\ 4.0 \\ 4.5 \\ 5.0\end{array}\right]$,

- the matrixes of the marginal and maximum acceptable concentrations of $\mathrm{BOD}_{5}$ and $C O D$ in water transported from the water reservoirs to the WPPs:

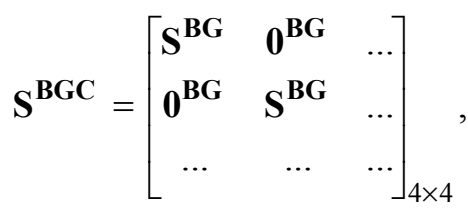

where: $\mathbf{S}^{\mathbf{B G}}=\left[\begin{array}{ccc}1 & 0 & \ldots \\ 0 & 1 & \ldots \\ \ldots & \ldots & \ldots\end{array}\right]_{4 \times 4}$,

and $\mathbf{0}^{\mathbf{B G}}=\left[\begin{array}{ccc}0 & 0 & \ldots \\ 0 & 0 & \ldots \\ \ldots & \ldots & \ldots\end{array}\right]_{4 \times 4}$, 
$\mathbf{S}^{\mathrm{CGC}}=\left[\begin{array}{ccc}\mathbf{S}^{\mathrm{CG}} & \mathbf{0}^{\mathrm{CG}} & \ldots \\ \mathbf{0}^{\mathrm{CG}} & \mathbf{S}^{\mathrm{CG}} & \ldots \\ \cdots & \ldots & \ldots\end{array}\right]_{4 \times 4}$,

where: $\mathbf{S}^{\mathbf{C G}}=\left[\begin{array}{ccc}10 & 0 & \ldots \\ 0 & 10 & \ldots \\ \ldots & \ldots & \ldots\end{array}\right]_{4 \times 4}$,

and $\mathbf{0}^{\mathbf{C G}}=\left[\begin{array}{ccc}0 & 0 & \ldots \\ 0 & 0 & \ldots \\ \cdots & \ldots & \ldots\end{array}\right]_{4 \times 4}$,

$\mathbf{S}^{\mathbf{B M C}}=\left[\begin{array}{ccc}\mathbf{S}^{\mathbf{B M}} & \mathbf{0}^{\mathbf{B M}} & \ldots \\ \mathbf{0}^{\mathbf{B M}} & \mathbf{S}^{\mathbf{B M}} & \ldots \\ \cdots & \ldots & \ldots\end{array}\right]_{4 \times 4}$,

where: $\mathbf{S}^{\mathbf{B M}}=\left[\begin{array}{ccc}7 & 0 & \ldots \\ 0 & 7 & \ldots \\ \ldots & \ldots & \ldots\end{array}\right]_{4 \times 4}$,

and $\mathbf{0}^{\mathbf{B M}}=\left[\begin{array}{ccc}0 & 0 & \ldots \\ 0 & 0 & \ldots \\ \ldots & \ldots & \ldots\end{array}\right]_{4 \times 4}$,

$\mathbf{S}^{\mathrm{CMC}}=\left[\begin{array}{ccc}\mathbf{S}^{\mathrm{CM}} & \mathbf{0}^{\mathrm{CM}} & \ldots \\ \mathbf{0}^{\mathrm{CM}} & \mathbf{S}^{\mathrm{CM}} & \ldots \\ \cdots & \ldots & \cdots\end{array}\right]_{4 \times 4}$,

where: $\mathbf{S}^{\mathbf{C M}}=\left[\begin{array}{ccc}30 & 0 & \ldots \\ 0 & 30 & \ldots \\ \ldots & \ldots & \ldots\end{array}\right]_{4 \times 4}$,

and $\mathbf{0}^{\mathbf{C M}}=\left[\begin{array}{ccc}0 & 0 & \ldots \\ 0 & 0 & \ldots \\ \ldots & \ldots & \ldots\end{array}\right]_{4 \times 4}$,

Attention: Some water purification processes are required when marginal concentrations of $\mathrm{BOD}_{5}$ or $C O D$ represented by matrixes $\mathbf{S}^{\mathbf{B G}}$ and $\mathbf{S}^{\mathbf{C G}}\left[\mathrm{g} / \mathrm{m}^{3}\right]$ are exceeded.
- the matrixes of the operation costs relations:

$\mathbf{A}_{1}=\left[\begin{array}{ccc}1000 & 0 & \ldots \\ 0 & 1000 & \ldots \\ \cdots & \ldots & \ldots\end{array}\right]_{4 \times 4}$,

$\mathbf{A}_{2}=\left[\begin{array}{ccc}\mathbf{A}_{22} & \mathbf{0}_{\mathrm{A2}} & \cdots \\ \mathbf{0}_{\mathrm{A2}} & \mathbf{A}_{22} & \cdots \\ \cdots & \cdots & \cdots\end{array}\right]_{4 \times 4}$,

where: $\mathbf{A}_{22}=\left[\begin{array}{ccc}10 & 0 & \ldots \\ 0 & 10 & \ldots \\ \ldots & \ldots & \ldots\end{array}\right]_{4 \times 4}$,

and $\mathbf{0}_{\mathbf{A 2}}=\left[\begin{array}{ccc}0 & 0 & \ldots \\ 0 & 0 & \ldots \\ \ldots & \ldots & \ldots\end{array}\right]_{4 \times 4}$,

$\mathbf{A}_{3}=\mathbf{A}_{4}=\mathbf{A}_{5}=\left[\begin{array}{ccc}\mathbf{A}_{55} & \mathbf{0}_{\mathbf{A 5}} & \ldots \\ \mathbf{0}_{\mathbf{A 5}} & \mathbf{A}_{55} & \ldots \\ \ldots & \ldots & \ldots\end{array}\right]_{4 \times 4}$,

where: $\mathbf{A}_{55}=\left[\begin{array}{ccc}0.1 & 0 & \ldots \\ 0 & 0.1 & \ldots \\ \cdots & \ldots & \ldots\end{array}\right]_{4 \times 4}$,

and $\mathbf{0}_{\mathbf{A 5}}=\left[\begin{array}{ccc}0 & 0 & \ldots \\ 0 & 0 & \ldots \\ \ldots & \ldots & \ldots\end{array}\right]_{4 \times 4}$

$\mathbf{A}_{6}=\mathbf{A}_{7}=\left[\begin{array}{ccc}0.001 & 0 & \ldots \\ 0 & 0.001 & \ldots \\ \ldots & \ldots & \ldots\end{array}\right]_{6 \times 6}$,

- the matrixes of the system structure:

$\mathbf{S}_{1}=\left[\begin{array}{ccc}\mathbf{S}_{11} & \mathbf{0}_{\mathbf{S 1}} & \ldots \\ \mathbf{0}_{\mathrm{S} 1} & \mathbf{S}_{11} & \ldots \\ \ldots & \ldots & \ldots\end{array}\right]_{4 \times 4}$, 
where: $\mathbf{S}_{\mathbf{1 1}}=\left[\begin{array}{lll}1 & 1 & \ldots\end{array}\right]_{1 \times 4}$,

and $\mathbf{0}_{\mathbf{S} 1}=\left[\begin{array}{lll}0 & 0 & \ldots\end{array}\right]_{1 \times 4}$,

$\mathbf{S}_{\mathbf{2}}=\left[\begin{array}{cccccc}-1 & 0 & 0 & 1 & -1 & 0 \\ 1 & -1 & 0 & 0 & 0 & -1 \\ 0 & 1 & -1 & 0 & 1 & 0 \\ 0 & 0 & 1 & -1 & 0 & 1\end{array}\right]_{4 \times 6}$

$\mathbf{S}=\left[\begin{array}{ccc}\mathbf{S}_{\mathbf{S}} & \mathbf{0}_{\mathbf{S}} & \ldots \\ \mathbf{0}_{\mathbf{S}} & \mathbf{S}_{\mathbf{S}} & \ldots \\ \ldots & \ldots & \ldots\end{array}\right]_{4 \times 4}$,

where: $\mathbf{S}_{\mathbf{S}}=\left[\begin{array}{ccc}1 & 0 & \ldots \\ 0 & 1 & \ldots \\ \ldots & \ldots & \ldots\end{array}\right]_{4 \times 4}$

and $\mathbf{0}_{\mathbf{S}}=\left[\begin{array}{ccc}0 & 0 & \ldots \\ 0 & 0 & \ldots \\ \ldots & \ldots & \ldots\end{array}\right]_{4 \times 4}$.

The duration of the simulation of the optimization model is $T=10 \mathrm{~s}$.

According to the results of the optimization models of the operation of the water management system and the data used for calculations, it may be stated that:

- when all of the water reservoirs are involved in the realization of the water demands for WPPs, then the total cost of the system operation is lower than the cost of the system operation while one of the water reservoir is inactive,

- if water is not distributed from a water reservoir to the WPPs because of poor water quality, then the water is transported from this water reservoir to other water reservoirs (to prevent from overfilling; in this article the changes in $\mathrm{BOD}_{5}$ and $C O D$ concentrations while water transportation among the water reservoirs are negligible because the volumes of water transported are much smaller then volumes of water in the water reservoirs).

\section{CONCLUSIONS}

The main purpose of water management systems is to supply water for agglomerations. The water demands may be satisfied by proper use of natural environment resources. The tendency of the current activities is an application of technical devices such as water reservoirs used as water storages, which can collaborate among themselves and with water purification plants. Each element of the system generates costs while coming into existence, as a new element of the water management system, and during the system functioning but each element performs also a specified function in water management systems. In the article the method of the optimal control of water management systems is proposed. The solution to the problem depends on the kind of data available, various restrictions and the main role of the system regarding the way of the expected functioning of the system. The presented example is a dynamic optimization problem (Chmielowski 2004; Chmielowski 2005; Górecki 2006; Górecki et al 1983) and the solution is an answer to real engineering problems concerning water management systems (Chmielowski 2004; Chmielowski 2005; Mikulski 1998; Słota 1997). 


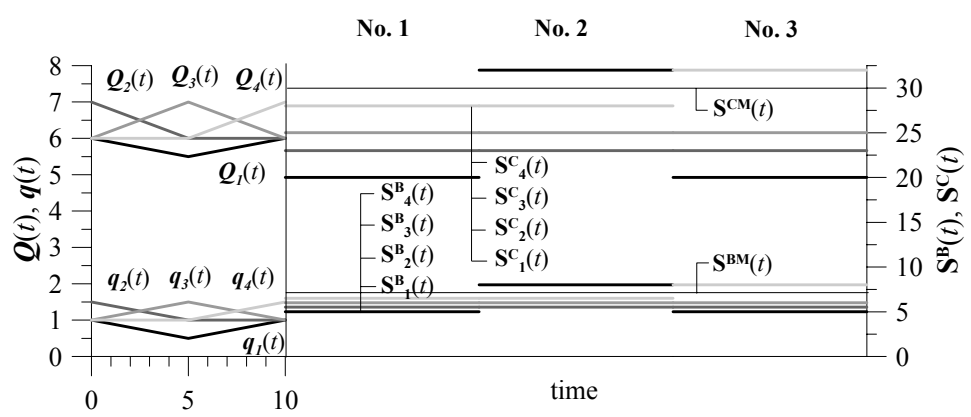

FIGURE 2. The expected inflows $\boldsymbol{Q}^{\boldsymbol{P}}(t)$, the required outflows $\boldsymbol{q}(t)$ and the values of $\mathbf{S}^{\mathbf{B}}(t)$ and $\mathbf{S}^{\mathbf{C}}(t)$ in each simulation model

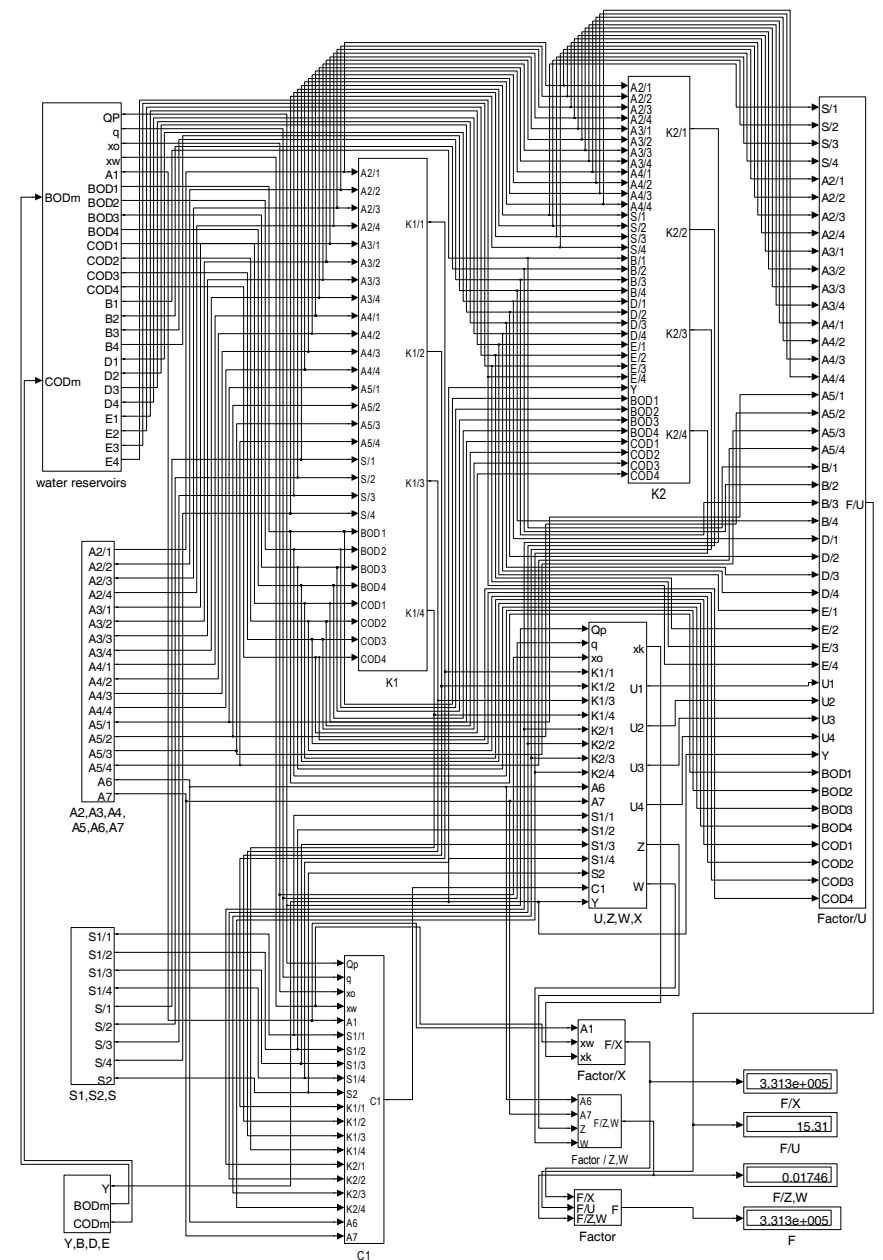

FIGURE 3. The scheme of the optimization model of water management system operation in Matlab/ /Simulink 


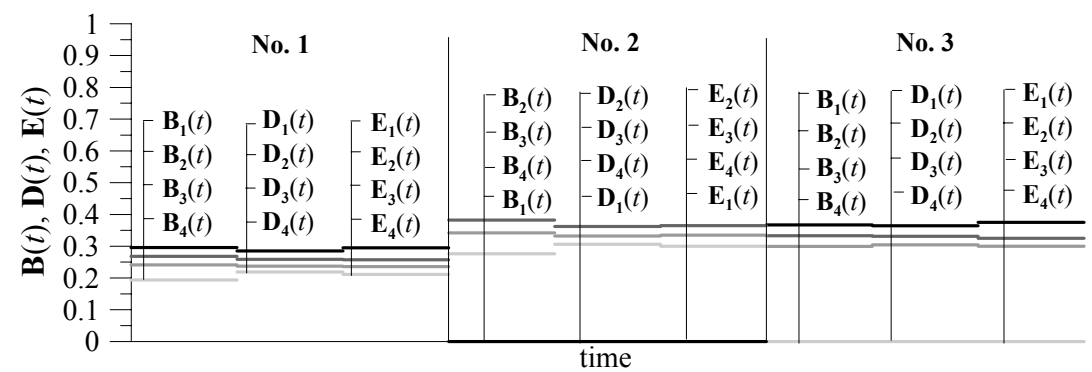

FIGURE 4. The values of calculated $\mathbf{B}(t), \mathbf{D}(t)$ and $\mathbf{E}(t)$ in each simulation model

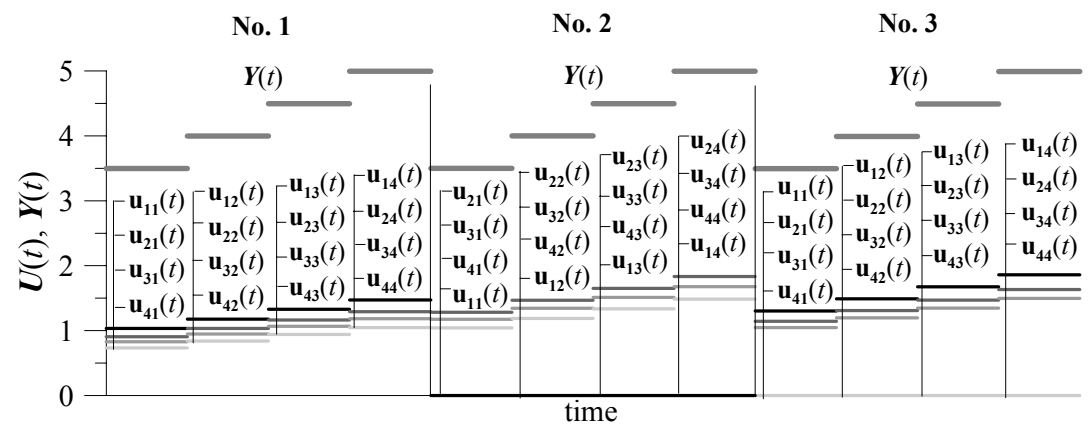

FIGURE 5. The values of the required $\boldsymbol{Y}(t)$ and calculated $\boldsymbol{U}(t)$ in each simulation model

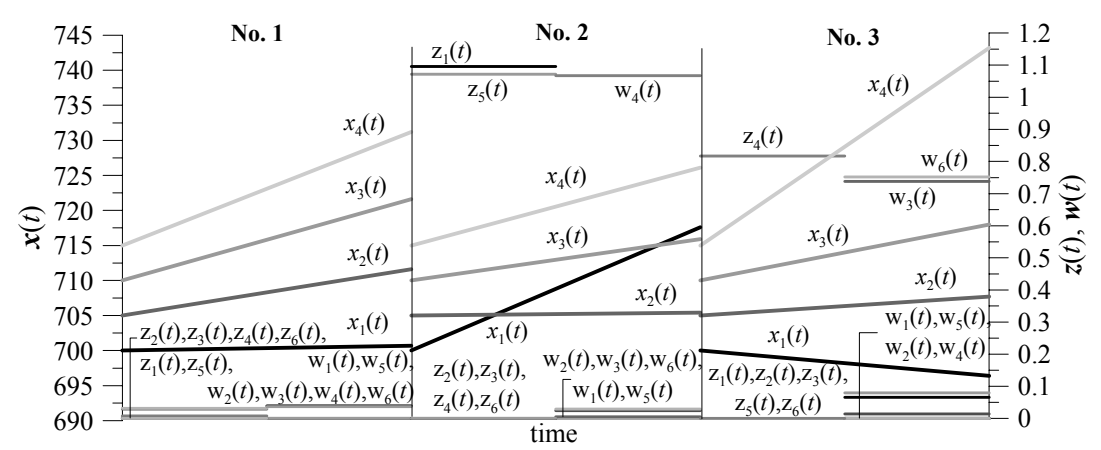

FIGURE 6. The values of calculated $\boldsymbol{z}(t), \boldsymbol{w}(t)$ and $\boldsymbol{x}(t)$ in each simulation model

TABLE 1 . The values of calculated $F$ in each simulation model

\begin{tabular}{|l|c|c|c|}
\hline & No. 1 & No. 2 & No. 3 \\
\hline$F$ & $1.521 \cdot 10^{5}$ & $3.313 \cdot 10^{5}$ & $2.451 \cdot 10^{5}$ \\
\hline$F\left(\boldsymbol{x}_{\boldsymbol{k}}(T)\right)$ & $1.521 \cdot 10^{5}$ & $3.313 \cdot 10^{5}$ & $2.451 \cdot 10^{5}$ \\
\hline$F(\boldsymbol{u}(t))$ & 10.95 & 15.31 & 12.75 \\
\hline$F(z(t), \boldsymbol{w}(t))$ & $2.335 \cdot 10^{-5}$ & $1746 \cdot 10^{-5}$ & $893.7 \cdot 10^{-5}$ \\
\hline
\end{tabular}




\section{SUMMARY}

In this work the optimal operation of the water management system is analysed. The fundamental technical elements of the system are the water reservoirs and the network of the pipelines among the water reservoirs and between the water reservoirs and the water purification plants (WPPs). While the simulations of the optimal system operation, the vectors of the optimal flows are calculated, so that the total costs of the system operation determined by the quality factor $F$ are minimal. The analytical solution for the dynamic optimization problem is the result of the application of the Pontryagin's maximum principle. The simulation models of the optimal operation of the water management system were created in Matlab/Simulink. While the analyses of the results, the optimal control of some actual water management systems may by studied.

\section{REFERENCES}

CHMIELOWSKI W. 2004: Metody wspomagania decyzji przy sterowaniu systemami zbiorników retencyjnych służących zaopatrzeniu w wodę. Wyd. Politechniki Krakowskiej, Kraków.

CHMIELOWSKI W. 2005: Zastosowania optymalizacji w gospodarce wodnej. Wyd. Politechniki Krakowskiej, Kraków.

GÓRECKI H. 2006: Optymalizacja i sterowanie systemów dynamicznych. Uczelniane Wyd. Naukowo-Dydaktyczne AGH, Kraków.

GÓRECKI H., FUKSA S., KORYTOWSKI A., MITKOWSKI W. 1983: Sterowanie optymalne w systemach liniowych z kwadratowym wskaźnikiem jakości. PWN, Warszawa.
MIKULSKI Z. 1998: Gospodarka wodna. PWN, Warszawa.

SŁOTA H. 1997: Zarządzanie systemami gospodarki wodnej. Instytut Meteorologii i Gospodarki Wodnej, Warszawa.

Rozporządzenie Ministra Środowiska z dnia 27 listopada 2002 r. w sprawie wymagań, jakim powinny odpowiadać wody powierzchniowe wykorzystywane do zaopatrzenia ludności w wodę przeznaczoną do spożycia (Dz.U. 2002 nr 204, poz. 1728).

Streszczenie: Optymalizacja pracy systemu wodno-gospodarczego $w$ warunkach określonych parametrów jakościowych i ilościowych wody. W artykule podjęto tematykę optymalnego sterowania systemem wodno-gospodarczym. Głównymi elementami technicznymi rozpatrywanego systemu wodno-gospodarczego są zbiorniki retencyjne, pomiędzy którymi możliwy jest przerzut wody, a także sieć połączeń zbiorników ze stacjami uzdatniania wody (SUW). Optymalizacja pracy systemu polega na wyznaczeniu odpowiednich tras transportu wody oraz wielkości natężeń jej przepływów ze zbiorników retencyjnych do SUW i wielkości ewentualnych przerzutów międzyzbiornikowych, tak aby łączne koszty eksploatacji systemu określone przyjętym wskaźnikiem jakości były minimalne. Analityczne rozwiązanie sformułowanego zadania optymalizacji otrzymano w wyniku zastosowania zasady maksimum Pontriagina w odniesieniu do przyjętego wskaźnika jakości. Na podstawie uzyskanych rozwiązań stworzono symulacyjny model komputerowy przedstawiający pracę systemu. Analiza otrzymanych wyników będzie mogła mieć wpływ na decyzje wspomagające sterowaniem realnie istniejących systemów wodno-gospodarczych.

Stowa kluczowe: gospodarka wodna, systemy wodno-gospodarcze, sterowanie optymalne.

\section{MS. received December 2011}

\author{
Authors' address: \\ Joanna Połomska, Wojciech Z. Chmielowski \\ Instytut Inżynierii i Gospodarki Wodnej \\ Politechnika Krakowska \\ ul. Warszawska 24, 31-155 Kraków, Poland \\ e-mail:jpolomska@poczta.fm \\ wchmielowski@poczta.onet.pl
}

